\title{
理事長ご挨拶
}

Greeting from the president of the Japan Geriatrics Society

\section{秋下 雅弘}

この度, 楽木宏実先生（大阪大学大学院医学系研究 科老年・総合内科学 教授) の後任として，本学会の 第 5 代理事長に就任いたしましたので，この場を借り てご挨拶させていただきます。

私は 1985 年に東京大学医学部を卒業した後, 同老 年病学教室に入り, 以後, 一貫して老年医学の診療, 研究，教育に従事してまいりました。本学会では，大 内尉義元理事長(虎の門病院院長)のもと幹事として, そして楽木前理事長のもと副理事長として, 多くのこ とを学ばせていただきました。その間，本学会の活動 が医学界を越えて世間に注目され，学会が発展する様 子を目の当たりにしてきました。超高齢社会を迎える 我が国のみならず，国際的にも老年医学および本学会 の重要性は増すばかりでしょう，そのような中，本学 会理事長を拝命することは責任重大であり，身を引き 締めてその任に当たるとともに，微力ながら精一杯努 めさせていただく所存です，以下に若干の所信を申し 述べます。

\section{「健康長寿達成を支える老年医学推進 5 か年計画」の遂行}

2018 年 6 月に策定された 5 か年計画の 5 本柱であ る「I. 老年医学・高齢者医療の普及・啓発」,「II. フ レイル予防・対策による健康長寿の達成」「III. 認知 症への効果的な早期介入と社会的施策の推進」,「IV. 高齢者の定義に関する研究の推進と国民的議論の喚 起」「V. 基礎老化研究の育成・支援」を着実に遂行
していきます。副理事長として本計画策定の一端を 担った身であり，現時点で本計画に異を唱えるつもり は全くありません，策定から 1 年が経過し, 予定より 早いか予定通りの進捗を示す事項が多いようですが, 遅れている事項については委員会やワーキンググルー プの新設・改組も含めて早急に手当てをしていきたい と考えています。

\section{老年病専門医および老年 (内) 科の認 知度向上と普及}

老年病専門医も老年（内）科も，高齢患者を専門に 診る医師あるいはそのような診療科であることは誰に でもわかるでしょうし，その名前を聞いたことがある という方もいるでしょう。そういう意味で一定の知名 度はあると言えるのかもしれません，しかし，どのよ うな病状になったら老年病専門医ないし老年（内）科 を受診するのかと問われると，さてどのくらいの方が 答えられるでしょうか? その答えは老年病専門医等の コーナーをご覧いただくとして，よく理解されていな い,つまり一般への認知度はまだ低いのが現状でしょ う. 5 か年計画の「I. 老年医学 - 高齢者医療の普及 · 啓発」とも関連することではありますが，任期中に少 しでも認知度を向上させるべく具体的なアクションを 起こします，当然のことながら，普及も使命であり， 地域医療に貢献するべく，老年病科専門医を増やすと ともに，老年内科の看板を揭げる医療機関を増やすよ う働きかけたいと思います。

一般社団法人日本老年医学会理事長 


\section{ダイバーシティの推進}

多様性は高齢者の特徵の一つであり，老年医学には 学際的で多彩な視点が求められます。したがって, 本 学会のたゆま嫶歩のために, 学会の活動を支えるメ ンバー (学会員, 委員会委員, 役員等) も多様な人材 で構成する必要があると考えます．この点は従来から 取り組まれてきたことですし，5か年計画にも盛り込 まれていますが, 動きを加速させたいと思います，若 手と女性の活用は言うに及ばず，定年後に高齢者医療
の道に進まれた方々，そして医療・介護・福祉の各専 門職にも参画していただきやすい環境作りを行うよう 努力いたします。

その他にも行うべきことはたくさんありますが， 5 か年計画と重複しますので省かせていただきます. 尚, 副理事長は荒井秀典先生（国際- 学術担当, 国立長寿 医療研究センター) と神㟝恒一先生 (総務・診療担当, 杏林大学）に抒願いし，未熟な理事長を支えていただ きます。どうかよろしくお願いいたします。

2019 年 6 月吉日 
秋下＼cjkstart雅弘（あきした まさひろ）先生 ご略歴

現職

東京大学 教授

大学院医学系研究科 加齢医学講座 老年病学分野, 老化制御学分野 (兼務)

東京大学高齢社会総合研究機構（兼務）

略歴

鳥取県生まれ

昭和 60 年 東京大学医学部卒業

平成 6 年東京大学医学部老年病学教室助手

平成 8 年 6 月 スタンフォード大学研究員

平成 8 年 9 月〜平成 10 年 12 月ハーバード大学ブリガム・アンド・ウイメンズ病院研究員. 帰国後前職（東京 大学助手).

平成 12 年 杏林大学医学部高齢医学講師

平成 14 年 杏林大学医学部高齢医学助教授

平成 16 年＼cjkstart東京大学大学院医学系研究科老年病学助教授 (平成 19 年職名変更により准教授)

平成 25 年 同教授

平成 26 年 東京大学高齢社会総合研究機構 教授（兼務）(現在まで）

同副機構長（平成 31 年 3 月まで）

平成 27 年東京大学医学部附属病院 副院長 (平成 31 年 3 月まで)

日本老年医学会での主な活動：

老年病専門医, 指導医. 理事, 代議員.

高齢者医療委員会委員長, ( ad hoc committee) 高齢者薬物療法のガイドライン作成のためのワーキンググループ

代表, 副理事長（平成 27 年 6 月～令和元年 6 月）などを歴任. 令和元年 6 月より理事長. 